\title{
Health-promoting activities of edible seaweed extracts from Chilean coasts: assessment of antioxidant, anti-diabetic, anti-inflammatory and antimicrobial potential
}

\section{Actividades promotoras de la salud de extractos de algas comestibles de las costas chilenas: evaluación del potencial antioxidante, antidiabético, antiinflamatorio $y$ antimicrobiano}

\begin{abstract}
The aim of this study was to evaluate the antioxidant, antidiabetic, anti-inflammatory and antimicrobial activities of three edible seaweed extracts from Chilean coasts: Pyropia orbicularis, Ulva spp, and Durvillaea antarctica. Seaweed extracts in methanol and $70 \%$ acetone were performed to evaluate antioxidant and antidiabetic activities, whereas $60 \%$ methanol was used to measure anti-inflammatory and antimicrobial activities. Acetone extracts from D. antarctica had the highest total phenolic content and consequently exhibited the strongest antioxidant activity, while methanol extract of this seaweed presented the highest $\alpha$-glucosidase inhibition (IC50 $=0.004 \mathrm{mg} \mathrm{mL}^{-1}$ ). In the tests against $E$. coli and Penicillium sp., the extracts obtained from Ulva spp. were the most effective and exhibited the maximum antiinflammatory effect against phorbol 12-myristate 13-acetate irritant agent (61.8\% inhibition) in mice. Results indicated that all evaluated Chilean seaweed extracts are promising candidates for application in functional foods and in the pharmaceutical industry.
\end{abstract}

Keywords: Antimicrobial; $\alpha$ - glucosidase; Bioactive compounds; Inflammatory inhibitors; Macroalgae.

\section{RESUMEN}

El objetivo de este estudio fue evaluar las actividades antioxidantes, antidiabéticas, antiinflamatorias y antimicrobianas de los extractos de tres algas marinas comestibles de las costas Chilenas (Pyropia orbicularis, Ulva spp. y Durvillaea antarctica). Se realizaron extractos de algas marinas en metanol y acetona al $70 \%$ para evaluar las actividades antioxidantes y antidiabéticas, mientras que el metanol al $60 \%$ se usó para actividades antiinflamatorias y antimicrobianas. Los extractos de acetona de D. antarctica tuvieron el mayor contenido de fenoles totales (TPC) y, en consecuencia, exhibieron la mayor actividad antioxidante, mientras que el extracto metanólico de estas algas presentó la mayor inhibición de la $\alpha$-glucosidasa (IC50=0,004 mg $\mathrm{mL}^{-1}$ ). En las pruebas contra E. coli y Penicillium sp., los extractos obtenidos de Ulva spp., actuaron como los más efectivos y exhibieron el máximo efecto antiinflamatorio contra el agente irritante de forbol 12-miristato 13-acetato
Vivian García ${ }^{1}$, Elsa Uribe ${ }^{1,2}$, Antonio Vega-Gálvez ${ }^{1 *}$, Carla Delporte ${ }^{3}$ Gabriela Valenzuela-Barra ${ }^{3}$, Jéssica López ${ }^{4}$, Alexis Pastén ${ }^{1}$.

*Corresponding autor: Antonio Vega-Gálvez, Food Engineering Department, Universidad de La Serena, Av. Raúl Bitrán 1305, La Serena, Chile. E-mail: avegag@userena.cl

Este trabajo fue recibido el 05 de marzo de 2020. Aceptado con modificaciones: 19 de junio de 2020. Aceptado para ser publicado: 26 de junio de 2020 .

(TPA) (inhibición del 61,8\%) en ratones. Por lo tanto, los resultados indican que todos los extractos de algas chilenas evaluados pueden ser candidatos prometedores para su aplicación en alimentos funcionales y en las industrias farmacéuticas.

Palabras clave: Antimicrobianos; $\alpha$ - glucosidasa; Compuestos bioactivos; Inhibidores inflamatorios; Macroalgas.

\section{INTRODUCTION}

Globally, demand for contaminant-free seaweed for use in developing functional foods and pharmaceuticals appears to be increasing. This could be attributed to the richness of compounds that seaweeds have with applications for both food and health'. These compounds of interest include pigments, 
lipids, polysaccharides, fatty acids and sterols, proteins and peptides, as well as many secondary metabolites such as mycosporine-like amino acids, phenolic compounds and terpenes, all of which are highly specific to different algal groups and even to species within these ${ }^{2}$. There is substantial evidence for the health benefits of algal-derived compounds ${ }^{3}$. For example, phlorotannins from the brown seaweed, Eisenia arborea ${ }^{4}$, or pheophytin-a from the green seaweed, Enteromorpha prolifera ${ }^{5}$, exhibited a significant suppression against mouse ear edema induced by several inflammatory inducers. Consequently, these compounds could provide protective effects over the pathogenesis of inflammatory diseases. Sanz-Pintos et $\mathrm{a}^{6}{ }^{6}$ analyzed the macromolecular antioxidants (or non-extractable polyphenols) of six edible seaweeds from Chile. They reported that this fraction possesses on average $42 \%$ of total polyphenol content and a remarkable antioxidant capacity. The efficacy of brown seaweed extracts ( $F$. vesiculosus and $P$. canaliculata) to inhibit enzymes involved in intestinal carbohydrate digestion and assimilation have also been shown. Moreover, these algal extracts may also have a functional potential for use in food aimed at lowering glycemic response ${ }^{7}$. On the other hand, a broad spectrum of in vitro antibacterial activity has been associated with phenolic compounds from algae, specifically against Staphylococcus aureus and Bacillus spp ${ }^{8}$. Considering the extensive data that is available on the bioactivities of different seaweed compounds, it would be interesting to research Chilean species, given that local conditions at the harvesting site such as light, nutrient, and temperature regimes considerably impact metabolite levels and thus bioactive composition ${ }^{2}$. Despite the fact that Chile has a great variety of seaweeds, especially edible kinds, Chilean seaweed has been little exploited. Most research about Chilean seaweed has focused on nutritional aspects , $10,11^{2}$ or selected chemical compounds of interest $t^{6,12,13,14,15}$. No previous study has investigated the bioactivities of Chilean seaweed extracts. Hence, this study aimed to obtain extracts from three edible Chilean seaweeds (Pyropia orbicularis, Ulva spp. and Durvillaea antarctica) and assess antioxidant, anti-diabetic, anti-inflammatory and antimicrobial activities.

\section{Materials and methods \\ 2.1 Seaweed harvest and sample preparation}

Fresh red, green and brown seaweeds, Pyropia orbicularis, Ulva spp. (Ulva lactuca Linnaeus and Ulva rigida Agardh) and Durvillaea antarctica, respectively, were harvested between April and October 2017 in the Coquimbo Region of Chile. Pyropia orbicularis (Tongoy coast: $30^{\circ} 15^{\prime} 27^{\prime \prime} \mathrm{S}$

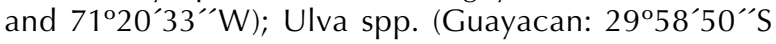
and $71^{\circ} 23^{\prime} 00^{\prime \prime} \mathrm{W}$ ) and Durvillea antartica (Puerto Aldea: $30^{\circ} 24^{\prime} 39^{\prime \prime} \mathrm{S}$ and $\left.71^{\circ} 63^{\prime} 03^{\prime \prime} \mathrm{W}\right)$. Seaweeds were selected by visual inspection according to color and absence of foreign matter and transported to the laboratory in a cooler. Then, seaweeds were washed with distilled water to remove epiphytes, sand and debris and immediately placed (in freeze drying trays) in a $-80{ }^{\circ} \mathrm{C}$ freezer for $24 \mathrm{~h}$, a batch was then placed horizontally onto three drying trays with a charge density of $2.19 \mathrm{~kg} \mathrm{~m}^{-2}$ and dried in a freeze dryer (VirTis Wizard 2.0 Advantage Plus XL-70, Gardiner, NY, USA) with $0.027 \mathrm{KPa}$ pressure for $68 \mathrm{~h}$. The freeze-dried samples were ground to powder using a basic analytical mill (IKA A-11, USA) and passed through a 35-mesh sieve of $500 \mu \mathrm{m}$ (U.S. Standard Sieve Series, Dual Manufacturing Co., USA). Powdered samples were sealed and stored in plastic bags at $5{ }^{\circ} \mathrm{C}$ until further analysis.

\subsection{Seaweed extraction procedure}

P. orbicularis, Ulva spp. and D. antarctica extracts were obtained using pure methanol and a mixture of acetone/ water $(70: 30, \mathrm{v} / \mathrm{v})$ as reported previously ${ }^{12,16}$ due to their effectiveness in generating antioxidant rich extracts. Briefly, powdered freeze-dried seaweeds were thoroughly mixed with solvents at a ratio of $1: 10 \mathrm{w} / \mathrm{v}$ in an orbital shaker (Boeco, OS20, Germany) at room temperature and $200 \mathrm{rpm}$ for $24 \mathrm{~h}$. Extractions were filtered through filter paper \#1 into $250 \mathrm{~mL}$ round bottom flasks. Solvents were removed using a rotary evaporator (Büchi R-210, Flawil, Switzerland) with the water-bath set at $40^{\circ} \mathrm{C}$. Dried residues were resuspended in $10 \mathrm{~mL}$ of pure methanol or a mixture of acetone/water $(70: 30, v / v)$. Extracts were obtained in triplicate, stored at -80 ${ }^{\circ} \mathrm{C}$ and then used to measure total phenolic content (TPC), antioxidant capacity and $\alpha$-glucosidase inhibitory activity.

\subsection{Determination of total phenolic content (TPC)}

TPC in the seaweed extracts was determined using a spectrophotometric method using Folin-Ciocalteau reagent ${ }^{12}$. The absorbance of the produced blue color was measured at $750 \mathrm{~nm}$, using a spectrophotometer (Spectronic 20 Genesys, NY, and USA). Results of TPC were expressed, based on a standard curve of gallic acid (Merck, Germany), as mg gallic acid equivalent (GAE) per 100 grams of dry matter (d.m.). All measurements were performed in triplicate.

\subsection{DPPH (2,2-diphenyl-1-picryl-hydrazyl) assay}

The DPPH assay was performed by preparing a solution of $50 \mu \mathrm{M} \mathrm{DPPH}$ in methanol or acetone/water (70:30). One hundred microliters of each seaweed extract were allowed to react with $3.9 \mathrm{~mL}$ of the DPPH solution for $30 \mathrm{~min}$ under dark conditions. The absorbance was read at $517 \mathrm{~nm}$ and results were expressed as $\mu \mathrm{mol}$ Trolox equivalents (TE) per $100 \mathrm{~g} \mathrm{~d} . \mathrm{m}$.

\subsection{ORAC (oxygen radical absorbance capacity) assay}

The ORAC assay was carried out according to Zhang et $\mathrm{al}^{17}$ in a Victor ${ }^{3}$ Multilabel Plate Reader (Perkin-Elmer, Turku, Finland). To each well of a polystyrene 96-well microplate (OptiPlateTM-96 F HB, Perkin-Elmer, Turku, Finland), $40 \mu \mathrm{L}$ of each seaweed extract produced with methanol or acetone/water (70:30) and resuspended in phosphate buffer $\mathrm{pH} 7.4$ (see Section 2.1) were mixed with $200 \mu \mathrm{L}$ of fluorescein $\left(100 \mu \mathrm{mol} \mathrm{L}^{-1}\right)$ prepared in phosphate buffer $\left(75 \mathrm{mmol} \mathrm{L}^{-1}, \mathrm{pH} 7.4\right)$ and incubated for $20 \mathrm{~min}$ at 
$37^{\circ} \mathrm{C}$. Then, $35 \mu \mathrm{L}$ of AAPH $\left(0.36 \mathrm{~mol} \mathrm{~L}^{-1}\right)\left(2,2^{\prime}\right.$-azobis (2-amidinopropane) dihydrochloride) was added to start the reaction. Fluorescence was read every $60 \mathrm{~s}$ ( $\lambda \mathrm{ex}=485$ $\mathrm{nm}$ and $\lambda \mathrm{em}=535 \mathrm{~nm}$ ), until fluorescence reading had declined to less than $5 \%$ of the initial value. Final ORAC values were calculated as $\mu$ mol TE per $100 \mathrm{~g}$ d.m., using the regression equation between Trolox concentration and net area under curve.

\section{$2.6 \alpha$-glucosidase activity assay}

Seaweed extracts obtained as described in Section 2.1 and their effects on $\alpha$-glucosidase activity were measured in a range of varying concentrations, according to Lordan et $\mathrm{al}^{7}$, slightly modified. A volume of $50 \mu \mathrm{L}$ of extract solution and $100 \mu \mathrm{L} \alpha$-glucosidase from Saccharomyces cerevisiae (Sigma G5003, USA) solution $\left(0.5 \mathrm{U} \mathrm{mL}^{-1}\right)$ in 0.1 $M$ sodium phosphate buffer $(\mathrm{pH}$ 6.9) was mixed in a 96-well microplate and incubated at $20{ }^{\circ} \mathrm{C}$ for $10 \mathrm{~min}$. Phosphate buffer containing $50 \mu \mathrm{l}$ of 4-nitrophenyl $\alpha$-d-glucopyranoside (Sigma N1377, Switzerland) was then added to each well. Absorbance at $405 \mathrm{~nm}$ was recorded every $30 \mathrm{~s}$ for 10 min using a Multilabel Plate Reader (Perkin-Elmer, Victor3, Turku, Finland) set to $20^{\circ} \mathrm{C}$. $\alpha$-glucosidase activity was calculated as the percentage obtained through the slope of each exponential curve. Inhibitory activity (\%) against $\alpha$-glucosidase vs seaweed extracts was also plotted. An exponential model was used to fit data so that IC50 was calculated as the concentration of seaweed extract required to produce $50 \% \alpha$-glucosidase inhibition.

\subsection{Determination of anti-inflammatory and antimicrobial activity}

2.7.1 Preparation of seaweed extracts

Powdered freeze-dried seaweed (10.0 g) was extracted with $60 \%$ methanol $(100 \mathrm{~mL})$ in an orbital shaker (Boeco, OS20, Germany) set at $200 \mathrm{rpm}$ at room temperature for $24 \mathrm{~h}$ and then filtrated. After filtration, methanol extracts were evaporated in a rotary evaporator (Büchi R-210, Flawil, Switzerland) with a water-bath set at $40{ }^{\circ} \mathrm{C}$, after which, all extracts were freeze-dried. $60 \%$ methanol was used in accordance with a previous study where the antimicrobial activity of extracts from brown seaweeds obtained with water, methanol and some mixtures (20, 40, 60 and 80\%) as solvents were compared. That study showed that a higher antimicrobial activity was obtained by $60 \%$ methanol compared to other solvents ${ }^{18}$.

\subsubsection{Anti-inflammatory activity}

Anti-inflammatory activity measurement of seaweed extracts was carried out according to Miño et $\mathrm{al}^{19}$ with some modifications. Adult male CF-1 mice (20-25 g) obtained from the stock at the Chilean Public Health Institute (ISP) were used. Dried seaweed methanol extracts (SME) (dissolved in acetone) were applied topically to the inner and outer surfaces of the right ear of each mouse at different doses (3.0, 1.5 and $0.75 \mathrm{mg} /$ ear). Likewise, $10 \mu \mathrm{L}$ of a solution of phorbol 12-myristate 13-acetate (TPA; $5 \mu \mathrm{g}$ in $20 \mu \mathrm{L}$ acetone) or arachidonic acid (AA; $2 \mathrm{mg}$ in $20 \mu \mathrm{L}$ acetone) were applied immediately after SME application. Negative control mice received only TPA or AA at the same concentration (100\% of inflammation). Left ear received only acetone. Indomethacin $(0.5 \mathrm{mg} / \mathrm{ear} / 20 \mu \mathrm{L})$ was used as reference drug for TPA and nimesulide $(1.0 \mathrm{mg} / \mathrm{ear} / 20$ $\mu \mathrm{L}$ ) for $\mathrm{AA}$, respectively. After $6 \mathrm{~h}$ (TPA administration) or $1 \mathrm{~h}$ (AA administration), the animals were sacrificed by $\mathrm{CO}_{2}$ asphyxiation. Disks of $6 \mathrm{~mm}$ diameter were removed from each ear and weight was determined. Edema was measured as the difference of the weights between the punches from right and left ears of the negative control and the treated animal groups, respectively. The experiments were performed in accordance with current "Guidelines on the care and use of animals for scientific purpose" and approved by the Animal Care and Use Committee of the Facultad de Ciencias Químicas y Farmacéuticas (University of Chile and ISP) (code of approval CICUAL-ISP-19062018).

\subsubsection{Antimicrobial activity}

\subsubsection{Microorganisms and growth conditions}

Seaweed methanol extracts were tested for antimicrobial activity against four microorganisms, Staphylococcus aureus (ATCC 25923) (Gram-positive), Escherichia coli (ATCC 25922) (Gram-negative), Saccharomyces cereceviceae (yeast) and Penicillium sp. (fungus). Microbial strains were maintained as $20 \%$ glycerol stocks at $-80^{\circ} \mathrm{C}$ in a nutrient broth (Difco), in the Microbiology Laboratory, Department of Food Engineering (University of La Serena, Chile). Prior to the experiments, cultures were transferred to solid or liquid media. The bacterial and fungi strains were aerobically grown in $5 \mathrm{~mL}$ of Müeller Hinton Broth (MHB, Merck) for $48 \mathrm{~h}$, continuously shaken at $120 \mathrm{rpm}$ at $37^{\circ} \mathrm{C}$. Cultures were then subcultured in tryptone soy broth (TSB, Difco) incubated for 12 to $24 \mathrm{~h}$ and used as the source of inoculum for each experiment. The bacterial and fungal suspensions for inoculation were adjusted to 0.5 McFarland standard turbidity ${ }^{13}$.

\subsubsection{Minimal inhibitory concentration (MIC) determination}

Antimicrobial activity of the seaweed methanol extracts was determined using the tube broth dilution assay ${ }^{20}$. A serial two-fold dilution ranging from 0.25 to $1000 \mathrm{mg} \mathrm{mL}^{-1}$ of extracts were prepared. Two milliliters of each dilution were incubated with $2 \mathrm{~mL}$ of $\mathrm{MHB}$ and an inoculum of 10 $\mu \mathrm{L}\left(106 \mathrm{CFU} \mathrm{mL} \mathrm{m}^{-1}\right.$ ) at $37^{\circ} \mathrm{C}$ for $24 \mathrm{~h}$ and at $30{ }^{\circ} \mathrm{C}$ for $48 \mathrm{~h}$, bacteria and fungus, respectively. MIC was determined by observing the lowest concentration of extract that inhibited visual bacterial growth. All assays were performed in triplicate and the results expressed in $\mathrm{mg} \mathrm{mL}^{-1}$.

\subsubsection{Minimum bactericidal concentration (MBC) determination}

$M B C$ was determined by inoculation of one aliquot of the last tube showing visible turbidity and negative tubes (absence of turbidity in MIC determination) on Mueller Hinton agar, 
incubated for $24 \mathrm{~h}$ at $37^{\circ} \mathrm{C}$ for bacteria and $48 \mathrm{~h}$ at $30^{\circ} \mathrm{C}$ for fungus, using the spread plate technique. Plates showing no growth on the Mueller Hinton agar indicated bactericidal effect of the extracts. The number of individuals in plates showing growth were counted manually. MBC was defined as the lowest concentration of each extract that completely prevented microbial growth on plates without the presence of other antimicrobial agents. All assays were performed in triplicate and the results expressed in $\mathrm{mg} \mathrm{mL}^{-1}$.

\subsection{Statistical analysis}

The experiments were conducted in triplicate and the data points are mean values \pm standard deviation (SD). When the statistical distribution was normal, one- or twoway ANOVA followed by Tukey's multiple comparisons test were conducted. When the statistical distribution was not normal, the Kruskal-Wallis non-parametric test was applied. Mann Whitney test was used for the individual comparisons. Significant differences was defined at the $5 \%$ level $(p<0.05)$ for all tests. The software employed for statistical analysis was Statgraphics Centurion XVI (Statistical Graphics Corp., Herdon, USA).

\section{RESULTS}

\subsection{Total phenolic content and antioxidant activity of seaweed extracts}

Table 1 presents the total phenolic content (TPC) and antioxidant activity from $P$. orbicularis, Ulva spp. and D. antarctica extracts obtained by two solvents, methanol and a mixture of acetone/water (70:30, v/v). Significant differences in TPC were found between seaweed species and between solvents used for extraction ( $\mathrm{p}<0.05$ ). TPC ranged from 74.9 to

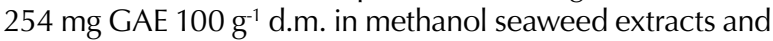
from 165 to $554 \mathrm{mg} \mathrm{GAE} 100 \mathrm{~g}^{-1} \mathrm{~d}$.m. in $70 \%$ acetone extracts.

Furthermore, the same table shows the antioxidant activity measured by the DPPH and ORAC assays, where Durvillea Antarctica showed greater activity with $566 \pm 5 \mu \mathrm{mol}$ TE 100 $\mathrm{g}^{-1} \mathrm{~d} . \mathrm{m}$. for methanol and $673 \pm 2 \mu \mathrm{mol}$ TE $100 \mathrm{~g}^{-1} \mathrm{~d}$.m. for acetone $70 \%$. This trend is similar for other results. ORAC values of $5501 \pm 1$ and $8808 \pm 2 \mu$ mol TE $100 \mathrm{~g}^{-1} \mathrm{~d}$.m. for methanol and acetone $70 \%$, respectively.

\section{2. $\alpha$-glucosidase activity of the seaweed extracts}

The comparison of $\alpha$-glucosidase activity of methanol and $70 \%$ acetone seaweed extracts are shown in Figure 1. All seaweed extracts obtained with both solvents affected $\alpha$-glucosidase activity in a dose-dependent manner, except for P. orbicularis methanol extract that did not present activity (Figure 1A). Nevertheless, the methanol extracts from Ulva spp. and $D$. antarctica showed better $\alpha$-glucosidase activities than aqueous acetone extracts. As a result, these methanol extracts completely suppress the activity of the enzyme at much lower concentrations than aqueous acetone extract (Figure 1B and C). As shown in table 2, D. antarctica methanol extract possessed the highest $\alpha$-glucosidase inhibition with the lowest IC50 value detected at $0.004 \mathrm{~g} \mathrm{~mL}^{-1}$, which could be the result of a higher content of phytochemical constituents of brown seaweed as compared to red and green ones.

\subsection{Anti-inflammatory activity of seaweed extracts}

The anti-inflammatory activity of the SME was evaluated by the method of ear edema in mice induced

Table 1. Total phenolic content (TPC) and antioxidant capacity of methanol and aqueous acetone extracts of three edible Chilean seaweeds.

\begin{tabular}{|c|c|c|c|c|}
\hline \multirow[t]{2}{*}{ Parameters } & \multirow[t]{2}{*}{ Solvent } & \multicolumn{3}{|c|}{ Seaweeds } \\
\hline & & Pyropia orbicularis & Ulva spp. & Durvillea antarctica \\
\hline TPC, & Methanol & $174 \pm 2.42^{\text {by }}$ & $74.9 \pm 1.89^{\mathrm{bz}}$ & $254 \pm 1.58^{\mathrm{bx}}$ \\
\hline (mg GAE $100 \mathrm{~g}^{-1}$ d.m) & Acetone:water (70:30) & $276 \pm 2.84^{\text {ay }}$ & $165 \pm 4.10^{\mathrm{az}}$ & $554 \pm 2.84^{\mathrm{ax}}$ \\
\hline DPPH, & Methanol & $79.8 \pm 5.77^{\mathrm{bz}}$ & $134 \pm 2.90^{\text {by }}$ & $566 \pm 4.76^{\mathrm{bx}}$ \\
\hline$\left(\mu \mathrm{mol}\right.$ TE $100 \mathrm{~g}^{-1}$ d.m) & Acetone:water (70:30) & $221 \pm 4.71^{\mathrm{az}}$ & $258 \pm 2.23^{\mathrm{ay}}$ & $673 \pm 2.06^{\mathrm{ax}}$ \\
\hline ORAC, & Methanol & $3958 \pm 4.54^{\text {by }}$ & $1937 \pm 2.76^{\mathrm{bz}}$ & $5501 \pm 1.00^{b x}$ \\
\hline$\left(\mu \mathrm{mol}\right.$ TE $\left.100 \mathrm{~g}^{-1} \mathrm{~d} . \mathrm{m}\right)$ & Acetone:water (70:30) & $4630 \pm 0.28^{\mathrm{ay}}$ & $3286 \pm 3.65^{\mathrm{az}}$ & $8808 \pm 2.43^{\mathrm{ax}}$ \\
\hline
\end{tabular}

Data are expressed as mean \pm standard deviation. ${ }^{\mathrm{a}-\mathrm{b}}$ Different superscript numbers in the same column indicate significant difference $(\mathrm{p}<0.05)$ and ${ }^{\mathrm{x}-\mathrm{z}}$ different superscript letters in the same row indicate significant difference $(\mathrm{P}<0.05)$.

2,2-diphenyl-1-picrylhydrazyl (DPPH); Radical Absorbance Capacity (ORAC); Gallic acid equivalents (GAE); Trolox equivalents (TE). 
by topical administration of two irritant agents, phorbol 12-myristate 13-acetate (TPA) and arachidonic acid (AA). The SME (3.0, 1.5 and $0.75 \mathrm{mg} /$ ear), indomethacin $(0.5$ $\mathrm{mg} / \mathrm{ear}$; positive control to TPA) and nimesulide $(1.0 \mathrm{mg} /$ ear; positive control to AA) were applied along with the irritant substances. Results showed that extracts from Ulva spp. and $P$. orbicularis significantly reduced $(\mathrm{p}<0.05)$ mice ear edema induced by both irritant agents in a dose-dependent manner (Table 3). The highest dose (3 mg/ear) of the extracts from Ulva spp. and $P$. orbicularis exhibited the maximum anti-inflammatory effect against TPA (61.8\% inhibition) and AA (57.2\% inhibition), respectively, comparable even using a reference drug in AA inflammatory model (nimesulide: $50.0 \%$ inhibition). In contrast, $D$. antarctica extract ( $3 \mathrm{mg} / \mathrm{ear}$ ) was able to produce only a slight anti-inflammatory activity $(22.9 \%$ inhibition) against TPA-induced mice ear edema model and was ineffective in the AA-induced mice ear edema model (Table 3).

\subsection{Antimicrobial activity of seaweed extracts}

Table 4 shows the results obtained for the minimal inhibitory concentration (MIC) and minimum bactericidal concentration (MBC) for P. orbicularis, Ulva spp. and $D$. antarctica extracts against $S$. aureus, E. coli, $S$. cereceviceae and Penicillium sp.

All tested extracts showed significant antimicrobial activity. No differences were observed among the MIC and $M B C$ values obtained for the different seaweed extracts tested against $S$. aureus with values $250 \mathrm{mg} \mathrm{mL}^{-1}$ and values $<1000 \mathrm{mg} \mathrm{mL}^{-1}$ for MIC and MBC, respectively. Similarly, differences were observed for $S$. cereceviceae with $125 \mathrm{mgmL}^{-1}$ and $<1000 \mathrm{mg} \mathrm{mL}^{-1}$ for MIC and MBC, respectively. In the tests against $E$. coli and Penicillium sp, the extracts obtained from Ulva spp. were more effective when compared to the other seaweed extracts since these presented lower MIC values. However, when assessing $\mathrm{MBC}$, both Ulva spp. and $D$. antarctica extracts showed the best values against Penicillium sp. $\left(250 \mathrm{mg} \mathrm{mL}^{-1}\right)$.

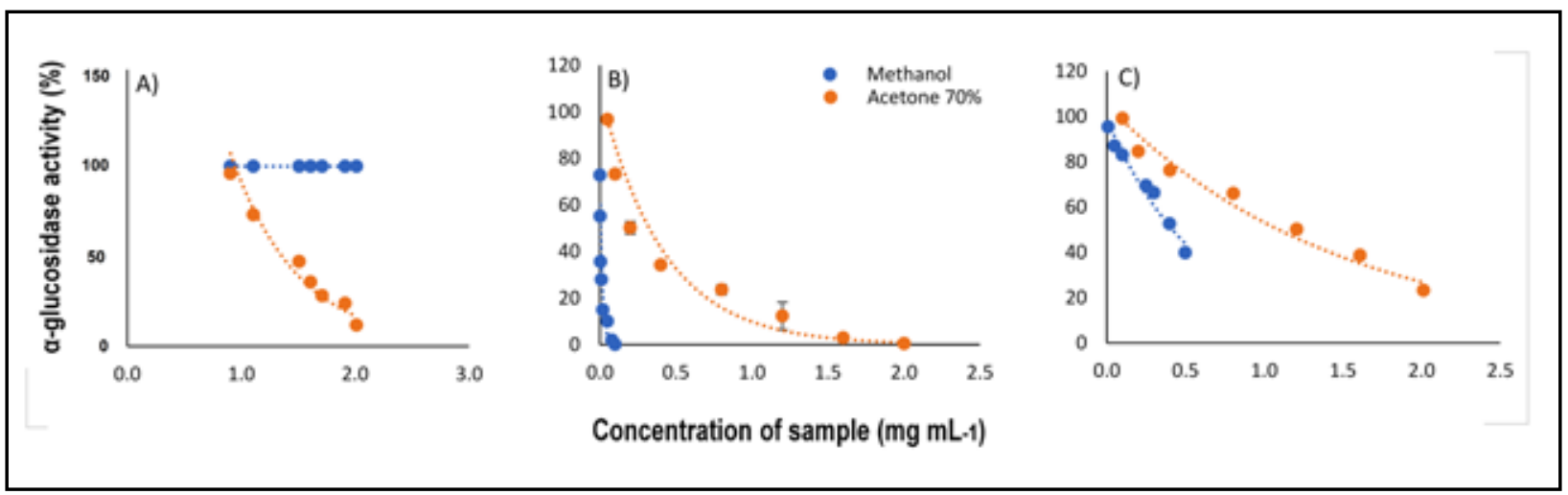

Figure 1: $\alpha$-glucosidase activity of the methanol extracts and aqueous acetone of three edible Chilean seaweeds. A) Pyropia orbicularis; B) Ulva spp.; C) Durvillea antarctica. Values are averages $(n=3)$, error bars are standard deviations.

Table 2. IC50 values of $\alpha$-glucosidase inhibitory activity of methanol and aqueous acetone extracts of three edible Chilean seaweeds.

\begin{tabular}{|lcccc|}
\hline \multirow{2}{*}{ Parameter } & Solvent & \multicolumn{3}{c|}{ Seaweeds } \\
\cline { 3 - 4 } & & Pyropia orbicularis & Ulva spp. & Durvillea antarctica \\
\hline IC $50\left(\mathrm{~g} \mathrm{~mL}^{-1}\right)$ & Methanol & $\mathrm{ND}$ & $0.416 \pm 0.005^{\text {by }}$ & $0.004 \pm 0.000^{\mathrm{bx}}$ \\
& Acetone:water $(70: 30)$ & $1.34 \pm 0.010^{\mathrm{ax}}$ & $1.09 \pm 0.038^{\mathrm{ay}}$ & $0.324 \pm 0.003^{\mathrm{az}}$ \\
& & & \\
\hline
\end{tabular}

Data are expressed as mean \pm standard deviation.

${ }^{a-b}$ Different superscript numbers in the same column indicate significant difference $(\mathrm{p}<0.05)$ and ${ }^{\mathrm{x}-\mathrm{z}}$ different superscript letters in the same row indicate significant difference $(\mathrm{P}<0.05)$. ND: Not detected. 
Table 3. Topical anti-inflammatory activity of the methanol extracts of three edible Chilean seaweeds against phorbol 12-myristate 13-acetate (TPA) and arachidonic acid (AA) - induced inflammation of mice ear edema.

\begin{tabular}{|c|c|c|c|}
\hline \multirow[t]{2}{*}{ Seaweeds } & \multicolumn{3}{|c|}{ Topical anti-inflammatory effects } \\
\hline & Dose (mg/ear) & $\% \mathrm{EA}_{\mathrm{TPA}} \pm \mathrm{SEM}$ & $\% \mathrm{EA}_{\mathrm{AA}} \pm \mathrm{SEM}$ \\
\hline Ulva spp. & 3.0 & $\uparrow 61.8 \pm 6.1^{*}, a$ & $\uparrow 37.7 \pm 5.0^{*}, a$ \\
\hline Ulva spp. & 1.5 & $45.0 \pm 7.1^{*}, \mathrm{~b}, \alpha$ & $24.6 \pm 3.8^{*}, \mathrm{~b}, a$ \\
\hline Ulva spp. & 0.75 & $25.3 \pm 7.5^{*}, \mathrm{a}, a$ & $5.1 \pm 8.6^{\mathrm{a}, \alpha}$ \\
\hline Pyropia oricularis & 3.0 & $\uparrow 35.4 \pm 3.9^{*}, \mathrm{~b}, \alpha$ & $\uparrow 57.2 \pm 6.1^{*}, \mathrm{c}$ \\
\hline Pyropia oricularis & 1.5 & $22.2 \pm 6.7^{*}, \mathrm{a}, a$ & $23.7 \pm 8.9^{*}, \mathrm{~b}, \mathrm{a}$ \\
\hline Pyropia oricularis & 0.75 & $10.4 \pm 4.7^{*}, \alpha$ & $7.2 \pm 7.0^{*}, \mathrm{a}, a$ \\
\hline Durvillea antarctica & 3.0 & $22.9 \pm 3.9^{*}, \mathrm{a}, \alpha$ & $1.3 \pm 8.3^{\mathrm{a}, \alpha}$ \\
\hline IND & 0.5 & $\uparrow 92.9 \pm 13.2^{*}$ & n.d \\
\hline NIM & 1.0 & n.d & $50.0 \pm 8.5^{*}, \mathrm{c}$ \\
\hline
\end{tabular}

$\uparrow$ maximum effect; $\mathrm{EA}_{\mathrm{TPA}}$ : topical anti-inflammatory effect against phorbol 12-myristate 13-acetate; EA $\mathrm{AA}_{\mathrm{A}}$ : topical anti-inflammatory effect against arachidonic acid; IND: indomethacin; NIM: nimesulide; n.d: not determined. An asterisk $\left({ }^{*}\right)$ denotes significant differences $(p<0.05)$ between samples respect to the negative control (100\% of inflammation); ${ }^{a-c}$ values in the same column with different superscripts indicate significant differences $(p<0.05)$ for each sample. Alpha $(\alpha)$ represents significant differences between the samples and the reference drug (NIM or IND).

Table 4. Minimal inhibitory concentration (MIC) and minimum bactericidal concentration (MBC) of methanol extracts of three edible Chilean seaweeds against gram-positive and gram-negative bacteria, yeast and mold.

\begin{tabular}{|lcccc|}
\hline \multirow{2}{*}{ Microorganisms } & Parameter & \multicolumn{3}{c|}{ Seaweeds } \\
\cline { 4 - 5 } & $\left(\mathbf{m g ~ m L}^{-\mathbf{1}}\right)$ & Pyropia orbicularis & Ulva spp. & Durvillea antarctica \\
\hline \multirow{2}{*}{ Staphylococcus aureus } & & & & 250 \\
MIC & 250 & 250 & $<1000$ \\
Saccherichia coli & MBC & $<1000$ & $<1000$ & 500 \\
& MIC & 500 & 250 & $<1000$ \\
Penicillium sp. & MBC & $<1000$ & $<1000$ & 125 \\
& MIC & 125 & 125 & 250 \\
& MBC & $<1000$ & $<1000$ & 250 \\
\hline
\end{tabular}

\section{DISCUSSION}

As shown in table 1, aqueous acetone was the most efficient solvent to extract TPC from the three kinds of edible seaweeds evaluated. This is due to the fact that polar solvents efficiently extract polar compounds, such as polyphenols bound to sugars or proteins, phlorotannins, glycosides and organic acids ${ }^{18,21}$. Farah Diyana et $\mathrm{a}^{22}$ also reported higher TPC values in the extracts obtained with $70 \%$ acetone than with methanol of two red seaweed species, K. alvarezii and K. striatum. Cian et $\mathrm{al}^{23}$ found that the TPC of the $80 \%$ acetone and methanol extracts of P. columbina extracts were approximately 50 and $30 \mathrm{mg}$ 
GAE $100 \mathrm{~g}^{-1}$ dry algae, respectively. It has been suggested that acetone has the ability to inhibit protein-polyphenol complex formation during extraction and breaking down hydrogen bonds formed between phenolic group and protein carboxyl group, resulting in a higher amount of polyphenols extracted ${ }^{18,21}$.

Among the evaluated seaweeds, D. antarctica showed the highest TPC level followed by P. orbicularis and Ulva spp. for both types of extracts (Table 1). This agrees with a previous study by Garcia-Casal et $\mathrm{al}^{24}$, that reported lower TPC value in Ulva spp. extract compared to red and brown seaweeds. Green seaweed is known to produce chemicals similar to those of red seaweed but lack the same degree of halogenation ${ }^{2}$. It has been previously reported that brown seaweeds present higher levels of TPC than green and red ones ${ }^{21,25}$. This might be due to the higher content of polyphenol phlorotannin compounds that are exclusively found in brown algae ${ }^{26}$, which ranges from 5 to $15 \%$ (dry weight) ${ }^{1}$.

Indeed, phlorotannins have been reported to have a strong antioxidant activity by preventing oxidative stress-induced cell damage in lung fibroblast cells ${ }^{3}$. Our data indicate that the highest antioxidant activity was determined in the $70 \%$ acetone extract from $D$. antarctica measured by both assays (DPPH and ORAC) (Table 1), suggesting that phenols present in extracts of $D$. antarctica may be the main constituents responsible for antiradical properties of these extracts ${ }^{26}$. However, other classes of antioxidant compounds such as fucoxanthin and sterols could be partially and simultaneously extracted with this solvent and contribute to the overall antioxidant activity of brown seaweed ${ }^{21}$.

Finally, our results were in agreement with others in which high antioxidant activity (by ORAC assay) was reported for $70 \%$ acetone extracts of brown seaweed species, including $F$. vesiculosus $\left(2567 \mu \mathrm{mol} \mathrm{TE} \mathrm{g}^{-1}\right.$ extract), F. serratus ( $2545 \mu \mathrm{mol} \mathrm{TE} \mathrm{g}{ }^{-1}$ extract), A. nodosum (1417 $\mu$ mol TE g-1 extract), L. hyperborea $(975 \mu$ mol TE g-1 extract) and $D$. antarctica $\left(8278 \mu \mathrm{mol} \text { TE } 100 \mathrm{~g}^{-1} \mathrm{~d} . \mathrm{m} .\right)^{12,21}$.

In this investigation, the activity of $\alpha$-glucosidase was studied against different concentrations of the extracts with methanol and acetone $70 \%$ of three algae because the use of $\alpha$-glucosidase activity suppressors could help to prevent diabetes as it suppresses carbohydrate digestion, thus delaying the process of glucose assimilation and resulting in a significant reduction of postprandial plasma glucose level ${ }^{7,27}$. The results support the findings of Lordan et $\mathrm{al}^{7}$, who studied several brown, red and green edible seaweed species. They found that brown seaweed extracts, in particular Fucus vesiculosus Linnaeus, was amongst the most potent seaweed extract for $\alpha$-glucosidase inhibition, exhibiting IC50 values of 0.32 (cold water extract) and $0.49 \mathrm{~g} \mathrm{~mL}^{-1}$ (ethanol extract). Several in vitro studies have related this inhibitory activity with phlorotannins such as phloroglucinol, dioxinodehydroeckol, eckol, dieckol, fucodiphloroethol, which are abundant in brown seaweeds ${ }^{16,28}$ or bromophenols such as 2,4,6-tribromophenol, 2,4-dibromophenol, bis (2,3,6-tribromo-4,5-dihydroxyphenyl) methane, which are present in green and red seaweeds ${ }^{29}$ or other polyphenols, such as chlorogenic acid ${ }^{30}$. The ability of polyphenols to inhibit certain enzymes is related to their interaction with proteins or polysaccharides (mainly in processed foods) ${ }^{27}$.

Inflammation is a complex process usually involving the release of several mediators such as prostaglandins (PGs), histamine, thermo-attractants, cytokines and proteinases ${ }^{31}$. For the in vivo topical test, two inflammatory agents, TPA and AA, were used because TPA induces longer-lived skin edema associated to protein kinase $C$ activation with the subsequent nuclear factor kappa B $(\mathrm{NF}-\kappa \mathrm{B})$ activation ${ }^{19,32}$. This transcription factor promotes the over production of inflammatory mediators such as tumor necrosis factor-alpha (TNF- $\alpha$ ), interleukins (IL-1b and IL-6) and cyclooxygenase $2(\mathrm{COX}-2)^{33,34}$. In contrast, inflammation induced by an AA irritant agent is related to increased activity of myeloperoxidase and elastase ${ }^{32}$. It has been established that this agent generates a rapid onset of short-lived edema associated with increases in prostaglandins (PGs), thromboxane TXB2 and leukotriene LTB4 with leukocyte extravasation ${ }^{35}$.

In this study, the extract from U/va spp. at different doses tested on AA-induced mouse ear edema tended to be weaker than that of TPA-induced mouse ear edema. On the other hand, the extract from $D$. antarctica was not able to inhibit the edema induced by AA, probably because the extract acts before AA metabolism ${ }^{19}$. Only extract obtained from $P$. orbicularis $(3.0 \mathrm{mg} /$ ear) produced an inhibition of AA edema in a much higher degree than the one obtained in the TPA (Table 3), suggesting an interference in AA metabolism ${ }^{36}$.

In a previous study, in Chilean seaweeds extracts, the presence of terpenoids (pacifenol, stypotriol triacetate and epitaondiol) ${ }^{37}$ was identified. They showed that these compounds possess anti-inflammatory actions, including mice ear edema attenuation induced by TPA. Terpenoid compounds have been established to possess an antiinflammatory effect by inhibiting the phospholipase A2 and blocking arachidonic acid metabolism ${ }^{31}$. In other studies, the presence of other bioactive compounds were reported such as pheophytin from Enteromorpha prolifera ${ }^{5}$, sterols (delta(5,7)-sterols, delta(5,7,9(11))-sterols among others) from Chlorella vulgaris ${ }^{38}$ and phlorotannins (eckol, 8,8'-bieckol, phlorofucofuroeckol-A and -B) from Eisenia arborea ${ }^{4}$ which also were effective against mouse ear inflammation induced by inflammatory inducers, especially TPA.Based on these results, the topical antiinflammatory activity of our seaweed extracts could be attributed to the different bioactive compounds present in them, which should be investigated in subsequent studies.

This study demonstrated that all algae studied have an antimicrobial effect. However, MIC and MBC values 
were higher than those reported in others studies. For example, Devi et a ${ }^{39}$ evaluated the antimicrobial potential of Haligra sp. seaweed extracted with methanol and reported stronger bactericidal effect against $S$. aureus compared to a standard antimicrobial agent (sodium benzoate). The study reported MBC values of $7.5 \mathrm{mg}$ $\mathrm{mL}^{-1}$ for seaweed extract and $30.0 \mathrm{mg} \mathrm{mL}^{-1}$ for sodium benzoate in Mueller Hinton agar, respectively. Wang et $\mathrm{al}^{40}$ evaluated the antimicrobial activity of phlorotannins present in Ascophyllum nodosum and reported that the growth of E. coli O157:H7 was successfully inhibited, exhibiting a MIC of $0.025 \mathrm{mg} \mathrm{mL}^{-1}$. El Shafay et $\mathrm{al}^{41}$ assessed the antimicrobial potential of four red seaweeds against a wide range of gram positive and gram-negative bacteria, including E. coli and S. aureus. According to the study of El Shafay et al ${ }^{41}$, the MICs of all extracts studied (diethyl ether, methanol, ethanol and chloroform extracts) ranged between 50 and $100 \mathrm{mg} \mathrm{mL}^{-1}$.

The aforementioned differences are probably accounted for by the different strains used in the determination of antimicrobial activity, different extraction techniques, and different seaweed composition used in each assay ${ }^{8}$. One explanation may be that, in the literature, the antimicrobial power of algae is defined by a wide range of compounds which depend on the type of extraction and the solvent of choice. Among the compounds mentioned in the literature with antimicrobial activity are proteins, polysaccharides, amino acids and polyunsaturated fatty acids (PUFAs). Seaweeds are often rich sources of PUFAs, especially high in $P$. orbicularis (52.63 g $100 \mathrm{~g}^{-1}$ of total fatty acid) ${ }^{13}$, Ulva spp. (41.94 g $100 \mathrm{~g}^{-1}$ of total fatty acid) 14 and D. antarctica (41.94 g $100 \mathrm{~g}^{-1}$ of total fatty acid) $)^{15}$. According to the review of Pina-Pérez et al, the mechanism of action of fatty acids as antimicrobials may be due to cell leakage derived from membrane damage.

\section{CONCLUSIONS}

In conclusion, all extracts from Chilean seaweed species ( $P$. orbicularis, Ulva spp. and D. antarctica) presented different levels of antioxidant, anti-diabetic, anti-inflammatory and antimicrobial activities. The results revealed that $D$. antarctica aqueous acetone extract contained the highest TPC level and had the greatest antioxidant activity; $D$. antarctica extract in methanol was the most potent for $\alpha$-glucosidase inhibition. In tests against $E$. coli and Penicillium sp., the extracts obtained from Ulva spp. were more effective when compared to the other seaweed extracts and showed the maximum anti-inflammatory effect against TPA. However, future studies should identify the bioactive compounds present in these seaweed extracts and determine the exact constituents responsible for such noteworthy activities.

Conflict of interest. The authors declare that there are no conflicts of interest.
Acknowledgments. The authors gratefully acknowledge FONDECYT Project 1160597 and DIDULS PT18331 (Dirección de Investigación y Desarrollo de la Universidad de La Serena) for providing financial support for the publication of this research.

\section{REFERENCES}

1. Agregán R, Munekata P.E.S, Franco D, Dominguez $R$, Carballo J, Lorenzo J.M. Phenolic compounds from three brown seaweed species using LC-DAD-ESI-MS/MS. Food Res Int. 2017; 99: 979-985.

2. Stengel DB, Connan $S$. Natural products from marine algae: methods and protocols. In Walker JM, Ed. Marine algae: a source of biomass for biotechnological applications. New York: Springer Science+Business Media. 2015; p. 1-30.

3. Bocanegra A, Bastida S, Benedí J, Ródenas S, Sánchez-Muniz FJ. Characteristics and nutritional and cardiovascular-health properties of seaweeds. J Med Food. 2009; 12: 236-258.

4. Sugiura Y, Tanaka R, Katsuzaki H, Imai K, Matsushita T. The anti-inflammatory effects of phlorotannins from Eisenia arborea on mouse ear edema by inflammatory inducers. I Funct Foods. 2013; 5: 2019-2023.

5. Okai Y, Higashi-Okai K. Potent anti-inflammatory activity of pheophytin aderived from edible green alga, Enteromorpha prolifera (Sujiao-nori). Int I Immunopharmacol. 1997; 19: 355-358.

6. Sanz-Pintos N, Pérez-Jiménez J, Buschmann AH, VergaraSalinas JR, Pérez-Correa JR, Saura-Calixto F. Macromolecular antioxidants and dietary fiber in edible seaweeds. J Food Sci. 2017; 82: 289-295.

7. Lordan S, Smyth TJ, Soler-Vila A, Stanton C, Ross RP. The $\alpha$-amylase and $\alpha$-glucosidase inhibitory effects of Irish seaweed extracts. Food Chem. 2013; 141: 2170-2176.

8. Pina-Pérez MC, Rivas A, Martínez A, Rodrigo D. Antimicrobial potential of macro and microalgae against pathogenic and spoilage microorganisms in food. Food Chem. 2017; 235: 34-44.

9. Ortiz J, Romero N, Robert P, Araya J, López-Hernández J, Bozzo C, et al. Dietary fiber, amino acid, fatty acid and tocopherol contents of edible seaweeds Ulva lactuca and Durvillaea antarctica. Food Chem. 2006; 99: 98-104.

10. Astorga-España MS, Mansilla A. Sub-Antarctic macroalgae: Opportunities for gastronomic tourism and local fisheries in the Region of Magallanes and Chilean Antarctic Territory. I Appl Phycol. 2014; 26: 973-978.

11. Astorga-España MS, Rodríguez-Galdón B, Rodríguez-Rodríguez EM, Díaz-Romero C. Amino acid content in seaweeds from the Magellan Straits (Chile). J Food Compos Anal. 2016; 53: 77-84.

12. Uribe E, Vega-Gálvez A, Vargas N, Pásten A, Rodríguez $K$, Ah-Hen KS. Phytochemical components and amino acid profile of brown seaweed Durvillaea antarctica as affected by air drying temperature. J Food Sci Technol. 2018; 55: 4792-4801.

13. Uribe E, Vega-Gálvez A, García V, Pastén A, Rodríguez K, López J, et al. Evaluation of physicochemical composition and bioactivity of a red seaweed (Pyropia orbicularis) as affected by different drying technologies. Dry Technol. 2020; 38: 1218-1230.

14. Uribe E, Vega-Gálvez A, García V, Pastén A, López J, Goñi G. Effect of different drying methods on phytochemical content and amino acid and fatty acid profiles of the green 
seaweed, Ulva spp. J Appl Phycol. 2019; 31: 1967-1979.

15. Uribe E, Pardo-Orellana C, Vega-Gálvez A, Ah-Hen KS, Pastén $A$, García V, et al. Effect of drying methods on bioactive compounds, nutritional, antioxidant, and antidiabetic potential of brown alga Durvillaea antarctica. Dry Technol. 2019.

16. Nwosu F, Morris J, Lund VA, Stewart D, Ross HA, McDougall GJ. Anti-proliferative and potential anti-diabetic effects of phenolic-rich extracts from edible marine algae. Food Chem. 2011; 126: 1006-1012.

17. Zhang L, Li J, Hogan S, Chung H, Welbaum GE, Zhou K. Inhibitory effect of raspberries on starch digestive enzyme and their antioxidant properties and phenolic composition. Food Chem. 2010; 119: 592-599.

18. Rajauria G, Jaiswal AK, Abu-Gannam N, Gupta S. Antimicrobial, antioxidant and free radical-scavenging capacity of brown seaweed Himanthalia elongata from western coast of Ireland. J Food Biochem. 2013; 37: 322-335.

19. Miño J, Moscatelli V, Hnatyszyn O, Gorzalczany S, Acevedo C, Ferraro G. Antinociceptive and antiinflammatory activities of Artemisia copa extracts. Pharmacol Res. 2004; 50: 59-63.

20. Beevi SS, Mangamoori LN, Hand V, Ramakrishna SD. Isothiocyanate profile and selective antibacterial activity of root, stem, and leaf extracts derived from Raphanus sativus L. Foodborne Pathog Dis. 2009; 6: 129-135.

21. Wang T, Jónsdóttir R, Ólafsdóttir G. Total phenolic compounds, radical scavenging and metal chelation of extracts from Icelandic seaweeds. Food Chem. 2009; 116: 240-248.

22. Farah Diyana A, Abdullah A, Shahrul Hisham ZA, Chan KM. Antioxidant activity of red algae Kappaphycus alvarezii and Kappaphycus striatum. Int Food Res J. 2015; 22: 1977-1984.

23. Cian RE, Fajardo MA, Alaiz M, Vioque J, González RJ, Drago $S R$. Chemical composition, nutritional and antioxidant properties of the red edible seaweed Porphyra columbina. Int J Food Sci Nutr. 2014; 65: 299-305.

24. García-Casal MN, Ramírez J, Leets I, Pereira AC, Quiroga, MF. Antioxidant capacity, polyphenol content and iron bioavailability from algae (Ulva sp., Sargassum sp. and Porphyra sp.) in human subjects. Br J Nutr. 2009; 101: 79-85.

25. Gupta S, Abu-Ghannam N. Recent developments in the application of seaweeds or seaweed extracts as a means for enhancing the safety and quality attributes of foods. Innov Food Sci Emerg Technol. 2011; 12: 600-609.

26. Farvin KHS, Jacobsen C. Phenolic compounds and antioxidant activities of selected species of seaweeds from Danish coast. Food Chem. 2013; 138: 1670-1681.

27. Parada J, Pérez-Correa JR, Pérez-Jiménez J. Design of low glycemic response foods using polyphenols from seaweed. J Funct Foods. 2019; 56: 33-39.

28. Moon HE, Islam MN, Ahn BR, Chowdhury SS, Sohn HS, Jung $H A$, et al. Protein tyrosine phosphatase $1 B$ and $\alpha$-glucosidase inhibitory phlorotannins from edible brown algae, Ecklonia stolonifera and Eisenia bicyclis. Biosci Biotechnol Biochem. 2011; 75: 1472-1480.
29. Wang W, Okada Y, Shi H, Wang S, Okuyama T. Structures and aldose reductase inhibitory effects of bromophenols from the red alga Symphyocladia latiuscula. I Nat Prod. 2005; 68: 620-622.

30. Abirami RG, Kowsalya S. Quantification and correlation study on derived phenols and antioxidant activity of seaweeds from Gulf of Mannar. J Herbs Spices Med Plants. 2017; 23: 9-17.

31. Lajili S, Azouaou SA, Turki M, Muller CD, Bouraoui A. Anti-inflammatory, analgesic activities and gastro-protective effects of the phenolic contents of the red alga, Laurencia obtuse. Eur J Integr Med. 2016; 8: 298-306.

32. Ban J, Oh JH, Kim DJ, Jeong H-S, Han SB, Hong JT. Antiinflammatory and arthritic effects of thiacremonone, a novel sulfur compound isolated from garlic via inhibition of NF- $\kappa B$. Arthritis Res Ther. 2009; 11: 1-13.

33. Gábor M. Models of acute inflammation in the ear. In Winyard, PG, Willoughby, DA Eds. Inflammation protocols. Humana Press, Totowa, NJ, 2003, pp 129-137.

34. Xian $Y-F$, Lin Z-X, Xu X-Y, Su Z-R, Chen J-N, Lai X-P, et al. Effect of Rhizoma Polygonati on 12-O-tetradecanoylphorbolacetate-induced ear edema in mice. J Ethnopharmacol. 2012; 142: 851-856.

35. Griswold DE, Marshall PJ, Lee JC, Webb EF, Hillegass LM, Wartell J, et al. Hanna N. Pharmacology of the pyrroloimidazole, SK\&F 105809-Il: anti-inflammatory activity and inhibition of mediator production in vivo. Biochem Pharmacol. 1991; 42: 825-831.

36. Camponogara C, Casoti R, Brusco I, Piana M, Boligon AA, Cabrini $D A$, et al. Tabernaemontana catharinensis leaves exhibit topical anti-inflammatory activity without causing toxicity. J Ethnopharmacol. 2019; 231: 205-216.

37. Gil B, Ferrándiz M.L, Sanz MJ, Terencio MC, Ubeda A, Rovirosa J, et al. Inhibition of inflammatory responses byepitaondiol and other marine natural products. Life Sci. 1995; 57: PL25-PL30.

38. Yasukawa K, Akihisa T, Kanno H, Kaminaga T, Izumida $M$, Sakoh $T$, et al. Inhibitory effects of sterols isolated from Chlorella vulgaris on 12-O-tetradecanoylphorbol13-acetate-induced inflammation and tumor promotion in mouse skin. Biol Pharm Bull. 1996; 19: 573-576.

39. Devi KP, Suganthy N, Kesika P, Pandian SK. Bioprotective properties of seaweeds: In vitro evaluation of antioxidant activity and antimicrobial activity against food borne bacteria in relation to polyphenolic content. BMC Complement. Altern Med. 2008; 8: 1-11.

40. Wang Y, Xu Z, Bach SJ, McAllister TA. Sensitivity of Escherichia coli to seaweed (Ascophyllum nodosum) phlorotannins and terrestrial tannins. Asian-Australas J Anim Sci. 2009; 22: 238-245.

41. El Shafay SM, Ali SS, El-Sheekh MM. Antimicrobial activity of some seaweeds species from Red sea, against multidrug resistant bacteria. Egypt J Aquat Res. 2016; 42: 65-74. 